\title{
Morfologia de plântulas de cinco leguminosas genistóides arbóreas do Brasil (Leguminosae-Papilionoideae)
}

\author{
Rodrigo Schütz Rodrigues ${ }^{1,3}$ e Ana Maria Goulart de Azevedo Tozzi²
}

Recebido em 26/06/2006. Aceito em 30/11/2006

\begin{abstract}
RESUMO - (Morfologia de plântulas de cinco leguminosas genistóides arbóreas do Brasil (Leguminosae-Papilionoideae)). Este trabalho tem como objetivo descrever, ilustrar e comparar a morfologia de plântulas de cinco espécies arbóreas ocorrentes no Brasil dos gêneros Bowdichia, Cyclolobium, Diplotropis, Ormosia e Poecilanthe, pertencentes ao clado genistóide (Leguminosae Papilionoideae). Plântulas fanero-epígeo-foliáceas são encontradas em Bowdichia virgilioides Kunth, Cyclolobium brasiliense Benth. possui plântulas faneroepígeo-armazenadoras, enquanto que Ormosia arborea (Vell.) Harms, Diplotropis martiusii Benth. e Poecilanthe parviflora Benth. apresentam plântulas cripto-hipógeo-armazenadoras. Outros relevantes caracteres morfológicos das plântulas são discutidos e comparados com os de espécies previamente estudadas nestes gêneros.
\end{abstract}

Palavras-chave: clado genistóide, Leguminosae-Papilionoideae, morfologia, plântula, Brasil

\begin{abstract}
Seedling morphology of five genistoid legume trees from Brazil (Leguminosae-Papilionoideae)). This work aims to describe, illustrate and compare the seedling morphology of five tree species of the genera Bowdichia, Cyclolobium, Diplotropis, Ormosia, and Poecilanthe, which belong to the genistoid clade (Leguminosae Papilionoideae). Phanero-epigeal-foliaceous seedlings are found in Bowdichia virgilioides Kunth, Cyclolobium brasiliense Benth. has phanero-epigeal-reserve seedlings, while Ormosia arborea (Vell.) Harms, Diplotropis martiusii Benth., and Poecilanthe parviflora Benth. possess crypto-hypogeal-reserve seedlings. Some other relevant seedling morphological characters are discussed and compared with those of previously studied species in these genera.
\end{abstract}

Key words: genistoid clade, Leguminosae-Papilionoideae, morphology, seedling, Brazil

\section{Introdução}

O conhecimento sobre a morfologia de plântulas é importante para a compreensão de vários processos ecológicos, tais como sucessão florestal, dispersão e germinação de sementes (Garwood 1995). Da mesma forma, caracteres morfológicos de plântulas têm sido empregados na sistemática como uma ferramenta útil para a delimitação de grupos em diferentes níveis taxonômicos (Garwood 1995; Förster 1997; Tillich 2003).

Duke \& Polhill (1981) apresentam uma revisão sobre os aspectos ecológicos e taxonômicos da morfologia de plântulas em Leguminosae. Desde então, alguns estudos de morfologia de plântulas com enfoque taxonômico têm sido realizados para alguns táxons da família, como Cicer L. (Nozzolillo 1985), Dalbergieae (Lima 1990), Lespedeza Mich. (Nemoto \& Ohashi
1993), Genisteae (López et al. 1998), determinados gêneros de Phaseoleae, Sophoreae, Swartzieae e Millettieae (sob Tephrosieae) (Oliveira 2001) e gêneros do clado Vatairea (Rodrigues \& Tozzi no prelo). A despeito disto, a morfologia de plântulas de vários representantes tropicais da subfamília Papilionoideae permanece ainda pouco conhecida.

Os gêneros Bowdichia Kunth, Cyclolobium Benth., Diplotropis Benth., Ormosia Jacks. e Poecilanthe Benth. são compostos por espécies predominantemente arbóreas, distribuídas na América do Sul tropical, com exceção de Ormosia, que é pantropical (Polhill 1981). Análises filogenéticas recentes baseadas em seqüências de DNA têm revelado que estes gêneros fazem parte do clado genistóide (Pennington et al. 2001; Wojciechowski et al. 2004), reconhecido principalmente pela presença alcalóides quinolizidínicos e pirrolizidínicos (Wink 2003).

\footnotetext{
1 Universidade Federal de Roraima, Centro de Ciências Biológicas e da Saúde, Departamento de Biologia, Campus do Paricarana, Av. Ene Garcez 2413, 69304-000 Boa Vista, RR, Brasil

2 Universidade Estadual de Campinas, Instituto de Biologia, Departamento de Botânica, C. Postal 6109, 13083-970 Campinas, SP, Brasil (anatozzi@unicamp.br)

3 Autor para correspondência: rodrigo@dbio.ufrr.br
} 
O clado genistóide é centrado na África e Eurásia, apresentando também representantes neotropicais e australianos. No Brasil, cerca de 15 gêneros apresentam representantes nativos do clado genistóide, dos quais dez são compostos predominantemente por espécies arbóreas e os demais constituídos geralmente por espécies herbáceas a arbustivas.

Para os gêneros arbóreos do clado genistóide ocorrentes no Brasil, dados sobre a morfologia de plântulas estão disponíveis na forma de breves relatos, que às vezes se restringem a ilustrações ou menções ao tipo morfológico (Duke 1965; 1969; Vogel 1980; Polhill 1981; Ricardi et al. 1987; Polak 1992; Moreira \& Moreira 1996; Ibarra-Manríquez et al. 2001; Rocas 2002; Ressel et al. 2004). Entretanto, para alguns gêneros como Poecilanthe e Cyclolobium não há dados disponíveis sobre morfologia de plântulas.

Este trabalho tem como objetivo ampliar o conhecimento sobre a morfologia de plântulas de representantes arbóreos brasileiros do clado genistóide, pela descrição, ilustração e comparação das plântulas de uma espécie de cada um dos gêneros Bowdichia, Cyclolobium, Diplotropis, Ormosia e Poecilanthe. Além disso, este estudo pretende investigar a relevância dos atributos de morfologia de plântulas para a sistemática destes cinco táxons.

\section{Material e métodos}

Plântulas das espécies selecionadas foram estudadas a partir de sementes coletadas no Brasil, com exceção de Diplotropis martiusii Benth., cujas plântulas foram coletadas sob a copa de uma planta adulta encontrada em Belém, Pará. Para cada espécie é referido o material-testemunha da origem das sementes (exemplar adulto), seguido do respectivo material-testemunha de plântula. As siglas se referem aos herbários do Departamento de Botânica da Universidade Estadual de Campinas (UEC) e do Instituto de Pesquisas Jardim Botânico do Rio de Janeiro (RB):

Bowdichia virgilioides Kunth - Exemplar adulto: BRASIL. Minas Gerais: Jaboticatubas, Rodrigues \& Tozzi 1002 (UEC) - plântulas: Rodrigues 1605 e 1607 (UEC).

Cyclolobium brasiliense Benth. - Exemplar adulto: BRASIL. São Paulo: Campinas, Santin s.n. (UEC 30964) - plântulas: Rodrigues 1658 (UEC).

Diplotropis martiusii Benth. - Exemplar adulto:
BRASIL. Pará: Belém, Meireles 396 (RB, UEC) plântulas: Meireles 397 (UEC).

Ormosia arborea (Vell.) Harms - Exemplar adulto: BRASIL. São Paulo: Gália, Guimarães Júnior 01 (UEC) - plântulas: Rodrigues 1615 (UEC).

Poecilanthe parviflora Benth. - BRASIL. São Paulo: Campinas, Rodrigues \& Flores 1582 (UEC, exemplar adulto) - plântulas: Rodrigues 1587 e 1594 (UEC).

Sementes maduras destas espécies, exceto de D. martiusii, foram lavadas em água corrente e escarificadas mecanicamente na região oposta ao hilo. Após, foram colocadas para germinar em lotes de, no mínimo, 20 sementes, em caixas tipo gerbox, sob uma camada de algodão recoberta por outra de papel de filtro, levemente umedecido com água destilada, à temperatura ambiente. Para acompanhar o desenvolvimento das plântulas, após a emissão da raiz primária, estas foram repicadas para sacos plásticos com mistura em partes iguais de terra vegetal e areia e mantidas sob condições ambientais de luz em casa de vegetação no Departamento de Botânica da Universidade Estadual de Campinas, Campinas, SP

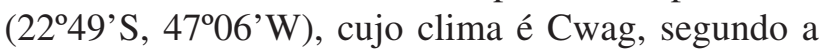
classificação de Koeppen (Santos \& Kinoshita 2003).

Complementarmente, para comparação e discussão com os resultados obtidos, foram observadas exsicatas de plântulas das seguintes espécies: Bowdichia nitida Spruce ex Benth.: BRASIL. Pará: Porto Trombetas, Faria \& Cunha 565 (RB) e Ormosia paraensis Ducke: BRASIL. Pará: Porto Trombetas, Faria \& Cunha (RB).

Neste trabalho, o conceito de plântula foi adaptado de Parra (1984), mas para padronizar as descrições e permitir comparações entre diferentes táxons, as medições foram realizadas até somente o terceiro eofilo, como em López et al. (1998). As medidas das estruturas foram tomadas quando completamente desenvolvidas e o comprimento das raízes quando da expansão do terceiro eofilo. Foram medidas 20 plântulas de todas as espécies, com exceção de D. martiusii, para a qual foram estudadas cinco plântulas. Os tipos morfológicos de plântulas foram classificados conforme Garwood (1996), que emprega dicotomicamente três caracteres de cotilédones (exposição, posição e textura) para reconhecer cinco tipos morfológicos de plântulas (siglas originais em inglês): PEF (faneroepígeo-foliáceo), PER (fanero-epígeo-armazenador), PHR (fanero-hipógeo-armazenador), CER (cripto- 
epígeo-armazenador) e CHR (cripto-hipógeoarmazenador).

Observações noturnas semanais foram feitas para analisar a ocorrência de movimentos nictinásticos em cotilédones e folíolos.

\section{Resultados e discussão}

A Tab. 1 sumariza os principais resultados sobre a morfologia de plântulas das cinco espécies estudadas, ilustradas nas Fig. 1-8.

Em todas as espécies estudadas, as sementes germinaram 5 a 14 dias após a semeadura, com exceção de Ormosia arborea. Nesta espécie, o início da germinação foi mais demorado, ocorrendo 27 dias após a semeadura, concordando com estudos realizados em outras espécies do gênero (Souza \& Silva 1998).

Descrição das plântulas - Bowdichia virgilioides Kunth (Fig. 1 e 6) - Plântula PEF. Raiz primária 30-40×1,0-1,3 mm, castanha, não tuberizada; raízes laterais pouco numerosas, ca. $4-5 \mathrm{~mm}$ compr. Colo ca. 1,5 mm diâm., branco-esverdeado. Hipocótilo 12-25 $\times 1,0-1,2 \mathrm{~mm}$, quadrangular, verde-claro passando a castanho quando lignificado, glabro. Cotilédones 13-15×10-12×0,6-0,8 mm, foliáceos, largamente elípticos, planos, verde-escuros, glabros em ambas as faces, ápice obtuso a arredondado, base obtusa ou levemente oblíqua, nervura principal e duas secundárias pouco impressas na face adaxial e somente a principal saliente na face abaxial, pecíolo 0,5-0,6 $\mathrm{mm}$ compr., não nictinásticos; gemas cotiledonares inconspícuas; glândulas intercotiledonares presentes. Epicótilo 3-7x 0,6-1 mm, cilíndrico, verde-claro, esparsamente pubescente; catafilos e lenticelas ausentes. Gemas axilares inconspícuas. Entrenó 1 3-6 mm compr., entrenó 2 3-4 mm compr. Eofilos do $1^{\circ}$ nó e subseqüentes alternos; estípulas 1,2-2,5 mm compr., linear-lanceoladas, glabras; glândulas nas axilas dos eofilos presentes; pecíolo e raque foliar canaliculados, pubescentes; folíolos opostos, raro alternos, os terminais geralmente maiores que os laterais, ovais, ambas as faces glabras, exceto por tricomas esparsos junto à nervura principal e margem na face abaxial, ápice agudo a obtuso, mucronado, base obtusa a arredondada, margem inteira, nervação broquidódroma, 5-7 nervuras secundárias, divergindo a $60-70^{\circ}$ da nervura principal; estipelas 0,8-1,0 mm, com glândulas na base; nictinastia descendente. Eofilos do $1^{\circ}$ nó 1-3-foliolados, pecíolo 5-8 mm compr., raque foliar nula a 3,0-3,5 $\mathrm{mm}$ compr., lâmina 9-15×4-7 mm; eofilos do $2^{\circ}$ nó 1-3-foliolados, pecíolo 7-8 mm compr., raque foliar nula a 2,5-3,0 $\mathrm{mm}$ compr., lâmina 12-14×6-8 mm; eofilos do $3^{\circ}$ nó

Tabela 1. Principais caracteres morfológicos de plântulas de espécies de Bowdichia, Cyclolobium, Diplotropis, Ormosia e Poecilanthe (Leguminosae Papilionoideae). Abreviações: PEF = plântula fanero-epígea-foliácea; PER = plântula fanero-epígeo-armazenadora; CHR = plântula cripto-hipógeo-armazenadora; - = caráter inaplicável em plântulas com cotilédones não emergentes; SD = sem dados disponíveis; compr. = comprimento; diâm. = diâmetro.

\begin{tabular}{|c|c|c|c|c|c|}
\hline Caracteres/Espécies & $\begin{array}{c}\text { Bowdichia } \\
\text { virgilioides } \\
\text { Kunth }\end{array}$ & $\begin{array}{c}\text { Cyclolobium } \\
\text { brasiliense } \\
\text { Benth. }\end{array}$ & $\begin{array}{c}\text { Diplotropis } \\
\text { martiusii } \\
\text { Benth. }\end{array}$ & $\begin{array}{c}\text { Ormosia } \\
\text { arborea } \\
\text { (Vell.) Harms }\end{array}$ & $\begin{array}{c}\text { Poecilanthe } \\
\text { parviflora } \\
\text { Benth. }\end{array}$ \\
\hline Plântula: tipo morfológico & PEF & PER & CHR & $\mathrm{CHR}$ & CHR \\
\hline Pecíolo cotilédones: compr. (mm & n) $\quad 0,5-0,6$ & $0,3-0,4$ & 5 & nulo & $4-6$ \\
\hline Base dos cotilédones: forma & obtusa levemente oblíqua & sagitada & - & - & - \\
\hline Glândulas intercotiledonares & presentes & ausentes & - & - & - \\
\hline Hipocótilo: forma & quadrangular & cilíndrico & cilíndrico & cilíndrico & cilíndrico \\
\hline Hipocótilo: diâm. (mm) & $1,0-1,2$ & $2,5-3,0$ & $4,5-5,0$ & $2,7-3,0$ & $1,5-2,0$ \\
\hline Epicótilo: compr. (mm) & $3-7$ & 27-32 & $100-130$ & $50-65$ & $16-30$ \\
\hline Axilas dos eofilos: glândulas & presentes & presentes & ausentes & presentes & presentes \\
\hline Folíolos: forma da base & obtusa a arredondada & cordada & obtusa a arredondada & cordada & obtusa a cuneada \\
\hline Foliolos: forma do ápice & agudo a obtuso & acuminado & acuminado & acuminado & acuminado a obtuso \\
\hline Folíolos: nictinastia & descendente & descendente & SD & descendente & descendente \\
\hline Eofilo $1^{\circ}$ nó: filotaxia & alterna & oposta & oposta & oposta & alterna \\
\hline $\begin{array}{l}\text { Folíolos do eofilo } 1^{\circ} \text { nó: } \mathrm{n}^{\circ} \mathrm{e} \\
\text { dimensão }(\mathrm{mm})\end{array}$ & $1-39-15 \times 4-7$ & $138-45 \times 30-35$ & $190-110 \times 40-50$ & $160-63 \times 35-38$ & $12-9 \times 1,5-6,0$ \\
\hline $\begin{array}{l}\text { Folíolos do eofilo } 2^{\circ} \text { nó: } \mathrm{n}^{\circ} \mathrm{e} \\
\text { dimensão }(\mathrm{mm})\end{array}$ & $1-312-14 \times 6-8$ & $141-46 \times 36-38$ & $170-80 \times 30-50$ & $157-60 \times 34-37$ & $111-20 \times 9-15$ \\
\hline $\begin{array}{l}\text { Folíolos do eofilo } 3^{\circ} \text { nó: } \mathrm{n}^{\circ} \mathrm{e} \\
\text { dimensão }(\mathrm{mm})\end{array}$ & $513-17 \times 8-10$ & $145-50 \times 40-45$ & $170-82 \times 35-41$ & $158-60 \times 34-37$ & $120-30 \times 11-25$ \\
\hline
\end{tabular}




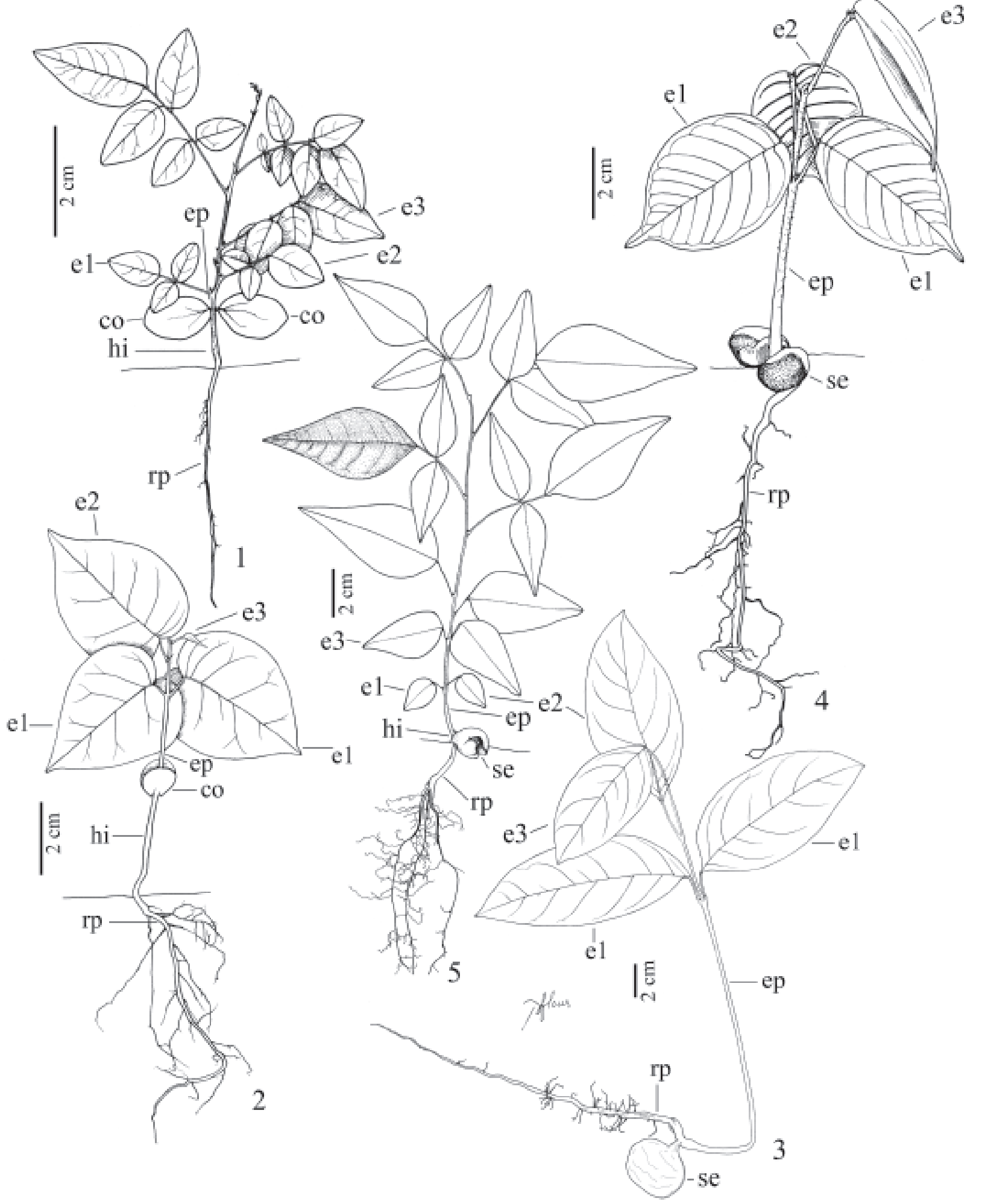

Figuras 1-5. Plântulas de representantes arbóreos do clado genistóide (Leguminosae). 1. Bowdichia virgilioides Kunth (Rodrigues 1605). 2. Cyclolobium brasiliense Benth. (Rodrigues 1658). 3. Diplotropis martiusii Benth. (Meireles 397). 4. Ormosia arborea (Vell.) Harms (Rodrigues 1615). 5. Poecilanthe parviflora Benth. (Rodrigues 1587). co = cotilédone; e $1=$ eofilo do $1^{\circ}$ nó; e $2=$ eofilo do $2^{\circ}$ nó; e3 = eofilo do $3^{\circ}$ nó; ep = epicótilo; hi = hipocótilo; rp = raiz primária; se = remanescente da semente. 
5-foliolados, pecíolo 6-7 mm compr., raque foliar 8-10 mm compr., lâmina 13-17×8-10 mm.

Cyclolobium brasiliense Benth. (Fig. 2) - Plântula PER. Raiz primária 70-80×1-2 mm, castanha, não tuberizada; raízes laterais numerosas, 30-50 mm compr. Colo ca. 2,5 mm diâm., castanho. Hipocótilo 25-30×2,5-3,0 mm, cilíndrico, verde-claro passando a castanho quando lignificado, glabro. Cotilédones 13-15×12-15×1,7-2,0 mm, armazenadores, largamente elípticos a orbiculares, planos, verdes, glabros em ambas as faces, ápice obtuso, base sagitada, nervura principal e duas secundárias pouco impressas na face adaxial e somente a principal saliente na face abaxial, pecíolo 0,3-0,4 mm compr., não nictinásticos; gemas cotiledonares inconspícuas; glândulas intercotiledonares ausentes. Epicótilo 27-32×1,2-1,5 mm, cilíndrico, verde-claro, esparsamente pubescente; catafilos ausentes; lenticelas elípticas, castanhas, ca. 0,5 mm compr. Gemas axilares conspícuas. Entrenó 1 8-12 mm compr., entrenó 2 7-9 mm compr. Eofilos do $1^{\circ}$ nó opostos, subseqüentes alternos; estípulas 1-2 mm compr., lanceoladas, esparsamente pubescentes; glândulas nas axilas dos eofilos presentes; pecíolo e raque foliar não canaliculados, esparsamente pubescentes; folíolos ovais, face adaxial glabra, face abaxial esparsamente pubescente, ápice acuminado, base cordada, margem inteira, nervação broquidódroma, 6-8 nervuras secundárias, divergindo a $70-80^{\circ}$ da nervura principal; estipelas $0,8-1,0 \mathrm{~mm}$, com glândulas na base; nictinastia descendente. Eofilos do $1^{\circ}$ nó 1-foliolados; pecíolo 6-7 $\mathrm{mm}$ compr., lâmina 38-45×30-35 mm; eofilos do $2^{\circ}$ nó 1 -foliolados, pecíolo 7-8 mm compr., lâmina 41-46×36-38 mm; eofilos do $3^{\circ}$ nó 1-foliolados; pecíolo 9-11 mm compr., lâmina 45-50×40-45 mm.
Diplotropis martiusii Benth. (Fig. 3) - Plântula CHR. Raiz primária 100-150×2-3 mm, castanho-clara, não tuberizada; raízes pouco numerosas, $15-20 \mathrm{~mm}$ compr. Colo ca. $5 \mathrm{~mm}$ diâm., castanho. Hipocótilo 1-2×4,5-5,0 mm, cilíndrico, verde, glabro. Cotilédones armazenadores, não emergentes, pecíolo $5 \mathrm{~mm}$ compr. Epicótilo 100-130×3-5 mm, cilíndrico, verde, glabro; catafilos ausentes; lenticelas elípticas, castanhas, $1 \mathrm{~mm}$ compr. Gemas axilares inconspícuas. Entrenó 1 30-52 mm, entrenó $228-32 \mathrm{~mm}$ compr. Eofilos do $1^{\circ}$ nó opostos, subseqüentes alternos; estípulas 1,0-1,5 mm, lineares, esparsamente pubescentes; glândulas nas axilas dos eofilos ausentes; pecíolo levemente canaliculado, esparsamente pubescente; folíolos elípticos, ambas as faces glabras, ápice acuminado, base obtusa a arredondada, margem inteira, nervação broquidódroma, 10-16 nervuras secundárias, divergindo a $60-80^{\circ}$ da nervura principal; estipelas 0,7-1,0 mm, lineares, com glândulas na base; nictinastia indeterminada. Eofilos do $1^{\circ}$ nó 1 -foliolados, pecíolo 4-12 mm compr.; lâmina 90-110×40-50 mm; eofilos do $2^{\circ}$ nó 1-foliolados, pecíolo 12-20 mm compr., lâmina 70-80×30-50 mm; eofilos do $3^{\circ}$ nó 1-foliolados, pecíolo 18-20 mm compr., lâmina 70-82×35-41 mm.

Ormosia arborea (Vell.) Harms (Fig. 4 e 7) - Plântula CHR. Raiz primária $100-120 \times 3,0-3,5 \mathrm{~mm}$, castanhoclara, não tuberizada; raízes laterais moderadamente presentes a abundantes, 8-27 mm compr. Colo 3,5-4 mm diâm., castanho. Hipocótilo 1-3×2,7-3,0 mm, cilíndrico, castanho, glabro. Cotilédones armazenadores, não emergentes, sésseis. Epicótilo 50-65×2-3 mm, cilíndrico, verde, pubescente; catafilos e lenticelas ausentes. Gemas axilares inconspícuas. Entrenó 1 10-14 mm, entrenó 2 14-17 mm compr. Eofilos do $1^{\circ}$ nó opostos,
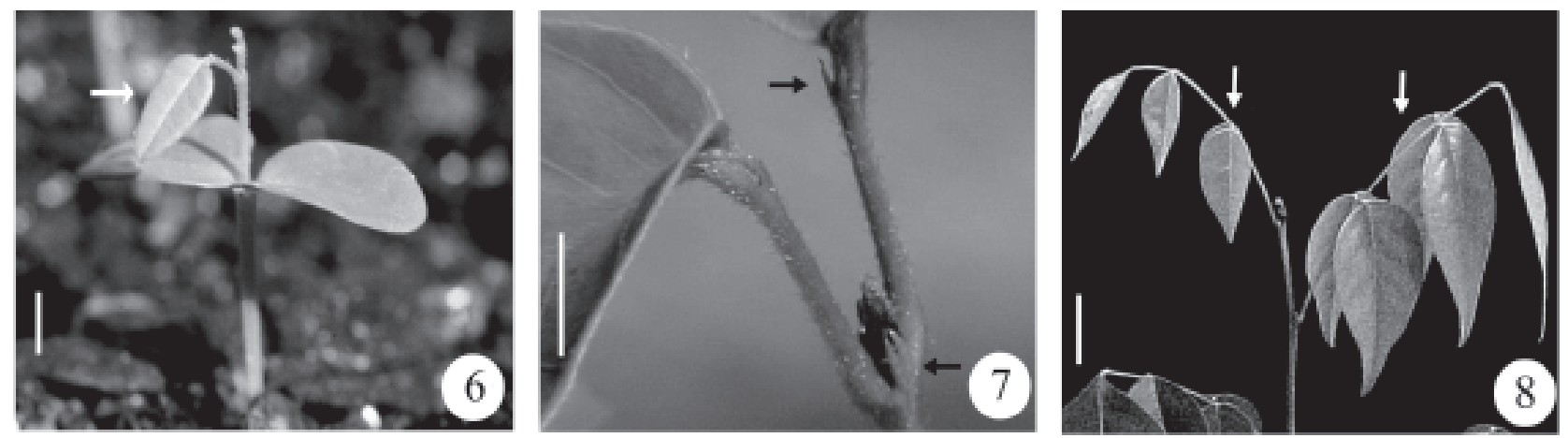

Figuras 6-8. Plântulas de representantes arbóreos do clado genistóide (Leguminosae). 6. Plântula de Bowdichia virgilioides Kunth, seta apontando o eofilo do $1^{\circ}$ nó 1 -foliolado (Rodrigues 1605). 7. Plântula de Ormosia arborea (Vell.) Harms (Rodrigues 1615); evidenciando as estípulas (seta inferior) e estipelas (seta superior) do eofilo do $1^{\circ}$ nó. 8. Plântula de Poecilanthe parviflora Benth., setas indicando a disposição dos folíolos como resultado do movimento nictinástico descendente (Rodrigues 1594). 
subseqüentes alternos; estípulas 2,8-3,2 $\mathrm{mm}$, linearlanceoladas, pubescentes; glândulas nas axilas dos eofilos presentes; pecíolo levemente canaliculado, pubescente; folíolos elípticos, ambas as faces glabras, exceto por tricomas esparsos junto à nervura principal na face abaxial, ápice acuminado, base cordada, margem inteira, nervação broquidódroma, 8-10 nervuras secundárias, divergindo a $55-65^{\circ}$ da nervura principal; estipelas linear-lanceoladas, 1,8-2,1 mm, persistentes, com glândulas na base; nictinastia descendente. Eofilos do $1^{\circ}$ nó 1 -foliolados, pecíolo 14-16 mm compr.; lâmina 60-63×35-38 mm; eofilos do $2^{\circ}$ nó 1-foliolados, pecíolo 15-18 mm compr., lâmina 57-60×34-37 mm; eofilos do $3^{\circ}$ nó 1-foliolados, pecíolo 20-22 mm compr., lâmina 58-60×34-37mm.

Poecilanthe parviflora Benth. (Fig. 5 e 8) - Plântula CHR. Raiz primária $80-130 \times 1,5-2,5 \mathrm{~mm}$, castanhoclara, não tuberizada; raízes laterais moderadamente presentes a abundantes, $15-55 \mathrm{~mm}$ compr. Colo 2,0-2,5 mm diâm., verde. Hipocótilo 1-7×1,5-2 mm, cilíndrico, verde, passando a castanho quando lignificado, glabro a esparsamente pubescente. Cotilédones armazenadores, não emergentes, pecíolo 4-6 mm compr. Epicótilo 16-30×1,2-1,6 mm, cilíndrico, verde, esparsamente pubérulo; catafilos ausentes; lenticelas orbiculares, castanhas, ca. 0,5 $\mathrm{mm}$ compr. Gemas axilares inconspícuas. Entrenó 1 3-10 mm, entrenó 2 13-28 mm compr. Eofilos do $1^{\circ}$ nó alternos, subseqüentes alternos; estípulas 0,7-1,0 mm, linearlanceoladas, glabras; glândulas nas axilas dos eofilos muitas vezes presentes; pecíolo e raque foliar canaliculados, pubescentes; folíolos opostos a subopostos, os terminais maiores que os laterais, ovais a largamente elípticos, ambas as faces glabras, ápice acuminado a obtuso, base obtusa a cuneada, levemente oblíqua, margem inteira, nervação broquidódroma, 6-8 nervuras secundárias, divergindo a $50-75^{\circ}$ da nervura principal; estipelas linear-lanceoladas, ca. $0,5 \mathrm{~mm}$, caducas, com glândulas na base; nictinastia descendente. Eofilos do $1^{\circ}$ nó 1 -foliolados, pecíolo 3-5 mm compr., lâmina 2-9×1,5-6,0 mm; eofilos do $2^{\circ}$ nó 1-foliolados, pecíolo 6-8 $\mathrm{mm}$ compr., lâmina 11-20×9-15 mm; eofilos do $3^{\circ}$ nó 1-foliolados, pecíolo 6-8 mm compr., lâmina 20-30×11-25 mm.

Comparação morfológica - Neste estudo foi observada uma variação nos tipos morfológicos de plântulas (sensu Garwood 1996) entre os táxons analisados: O. arborea, P. parviflora e D. martiusii apresentam plântulas CHR, B. virgilioides possui plântulas PEF, enquanto que $C$. brasiliense tem plântulas PER.
A forma do hipocótilo em corte transversal é quadrangular em $B$. virgilioides ou circular nas demais espécies. Por outro lado, o diâmetro do hipocótilo permite distinguir as três espécies CHR entre si, bem como as duas espécies com plântulas fanero-epígeas.

Com relação aos cotilédones, nas espécies com plântulas $\mathrm{CHR}$, os cotilédones podem ser sésseis em $O$. arborea ou peciolados em D. martiusii e P. parviflora. Nas espécies com plântulas faneroepígeas (PEF ou PER), é possível distinguir $B$. virgilioides de $C$. brasiliense pela forma da base dos cotilédones (Fig. 1 e 2).

Os epicótilos mais longos foram encontrados em D. martiusii (Fig. 3) e em O. arborea (Fig. 4), o que poderia ser esperado, considerando que o epicótilo em plântulas CHR geralmente contribui significativamente para a altura da plântula (Garwood 1995). Entretanto, o comprimento menor ou aproximadamente igual do epicótilo de $P$. parviflora em comparação com o de C. brasiliense, é um resultado que não confirma esta tendência. Contudo, é importante ressaltar que D. martiusii teve suas plântulas coletadas diretamente no campo e assim, as condições distintas de luminosidade podem ter resultado em um epicótilo muito mais longo que as demais espécies CHR. Por sua vez, $B$. virgilioides pode ser distinta de todas as espécies estudadas pelas menores dimensões do epicótilo.

Com relação aos eofilos, $O$. arborea, D. martiusii e $C$. brasiliense apresentam eofilos do primeiro nó opostos e 1-foliolados, P. parviflora alternos e 1-foliolados e $B$. virgilioides alternos e 1-3-foliolados (Fig. 1-5). O número de folíolos dos dois eofilos subseqüentes pode separar $B$. virgilioides das demais espécies. Além disso, as dimensões, a forma da base e do ápice da lâmina dos eofilos são caracteres que conjuntamente permitem distinguir as espécies entre si. Por outro lado, todas as espécies estudadas são estipuladas e apresentam estipelas. Desta forma, foi possível confirmar a ocorrência destas estruturas em O. arborea (Fig. 7) e O. paraensis, que geralmente são de difícil observação em materiais adultos tombados em herbários e por isso não assinaladas por Rudd (1965).

Movimentos nictinásticos de folíolos, embora comuns em Leguminosae, são geralmente pouco descritos para plântulas na literatura. Os padrões na nictinastia podem auxiliar na caracterização de determinados grupos, como verificado por Baudet (1974) para a tribo Phaseoleae (Papilionoideae) e Rodrigues \& Tozzi em alguns gêneros do clado Vatairea. Entretanto, nas espécies estudadas, os 
folíolos apresentam somente movimentos nictinásticos descendentes, ou seja, voltam-se para baixo e expõem sua face adaxial (Fig. 8), com exceção de D. martiusii, cuja nictinastia é desconhecida. Deste modo, este padrão observado nas quatro espécies corresponde ao tipo "D" de nictinastia proposto por Baudet (1974). Em contraposição, nenhuma espécie estudada apresentou nictinastia cotiledonar.

Em todas as espécies estudadas foram encontradas glândulas na base das estipelas e nas axilas dos eofilos, com exceto por D. martiusii, que não apresentou glândulas nas axilas dos eofilos. Por sua vez, somente em Bowdichia virgilioides foram observadas glândulas intercotiledonares. Todas estas estruturas são inicialmente branco-esverdeadas, passando a avermelhadas, lembrando coléteres por sua forma e posição. Entretanto, como não foram efetuados estudos anatômicos destas estruturas, optou-se por não empregar este termo, que deve ser atribuído para estruturas que secretam fluídos viscosos mucilaginosos ou resinosos (Thomas 1991).

Bowdichia compreende duas espécies (Pennington et al. 2005), B. virgilioides, que habita diversas fisionomias de savana na América do Sul e B. nitida Spruce ex Benth., que ocorre predominantemente em matas de terra-firme da Amazônia. Os resultados confirmam para $B$. virgilioides o tipo morfológico $\mathrm{PEF}$, referido anteriormente por Ressel et al. (2004). A espécie apresenta uma variação no número de folíolos no eofilo do primeiro nó (Fig. 1 e 6), com a ocorrência de indivíduos 1-foliolados e 3-foliolados, na proporção de 1:2. Semelhante variação também tem sido encontrada em algumas espécies de Acosmium s.l. (R.S. Rodrigues \& A.M.G.A. Tozzi, dados não publicados). Bowdichia nitida também apresenta plântulas PEF, o que indica que o tipo de plântula é conservativo no gênero. Além disso, ambas as espécies de Bowdichia têm hipocótilo quadrangular, o que as distingue das demais analisadas neste trabalho. A presença de hipocótilos de 40-45 mm compr. e epicótilos de 38-40 mm compr., marcadamente mais longos que os de $B$. virgilioides, com hipocótilos de 12-25 mm compr. e epicótilos de 3-7 mm compr., pode representar uma estratégia de $B$. nitida para estabelecer plântulas no interior de florestas, com a devida cautela pela pequena amostragem e possíveis condições de luminosidade distintas durante seu cultivo.

Diplotropis apresenta 12 espécies (Lima 1985), cuja morfologia de plântulas havia sido estudada somente em D. purpurea (Rich.) Amshoff. Esta espécie apresenta plântulas CHR, com eofilos do primeiro nó 1-foliolados e alternos (Polhill 1981; Polak 1992). Em D. martiusii, o tipo morfológico e o número de eofilos do primeiro nó concordam com os encontrados em $D$. purpurea, podendo ser distintas pela filotaxia dos eofilos do primeiro nó, oposta em D. martiusii.

Ormosia é um gênero com cerca de 130 espécies, das quais cerca de 80 ocorrem nos neotrópicos e as demais na Ásia e Austrália (Pennington et al. 2005). No gênero foram encontradas plântulas com cotilédones armazenadores, localizados abaixo ou no nível do solo. Assim, estes podem ser emergentes (plântulas PHR) em $O$. discolor Spruce ex Benth. (Moreira \& Moreira 1996), O. macrocalyx Ducke (Moreira \& Moreira 1996), O. fastigiata Tul. (Ressel et al. 2004) e em duas espécies não determinadas deste gênero (Duke 1969; Vogel 1980), ou não emergentes (plântulas CHR), em $O$. arborea, $O$. aff. tovarensis Pittier (Ricardi et al. 1987), O. venezolana Rudd (Ricardi et al. 1987), O. panamensis Benth. (IbarraManríquez et al. 2001), O. paraensis Ducke (Polhill 1981), O. excelsa Spruce ex Benth. (Moreira \& Moreira 1996), O. coutinhoi Ducke (Polak 1992) e O. krugii Urb. (Duke 1965). As informações disponíveis indicam que as espécies neotropicais de Ormosia apresentam eofilos do primeiro nó 1-foliolados. Isto se contrapõe à única espécie asiática com morfologia de plântula conhecida (Ormosia sp.), que apresenta eofilos do primeiro par 3-foliolados (Vogel 1980). Nas espécies neotropicais os eofilos do primeiro nó são geralmente opostos, com exceção de O. krugii e O. coutinhoi, com eofilos alternos.

Os resultados obtidos neste trabalho representam o primeiro relato da morfologia de plântulas para os gêneros Poecilanthe e Cyclolobium. Estes gêneros são considerados bastante relacionados filogeneticamente com base em evidências químicas e seqüências de DNA (Pennington et al. 2001; Warwick \& Pennington 2002; Ross \& Crisp 2005). Ambos os gêneros podem ser distintos entre si pelo tipo morfológico de plântula. Entretanto, cabe ressaltar que, enquanto Cyclolobium é monoespecífico (Warwick \& Pennington 2002), Poecilanthe compreende dois grupos distintos de espécies, totalizando cerca de 10-12 espécies (Ross \& Crisp 2005) e, desta forma, estudos adicionais em Poecilanthe são necessários para verificar o valor sistemático dos caracteres de plântula.

Por fim, os resultados evidenciaram variação dos tipos morfológicos e de vários caracteres de plântulas, indicando seu potencial sistemático para os táxons 
estudados. Desta forma, enfatiza-se a necessidade de ampliar estudos em elementos neotropicais e paleotropicais arbóreos e não-arbóreos do clado genistóide para a avaliação da relevância taxonômica da morfologia de plântulas neste grupo de Papilionoideae.

\section{Agradecimentos}

Agradecemos Andréia S. Flores pela leitura e sugestões, Paulo Guimarães Júnior pelo envio de sementes, José Eduardo Meireles pelo material de D. martiusii, Patrícia S. Flores pelas ilustrações, FAPESP (processo 00/09429-0) e CNPq (processo 150345/2005-4), respectivamente pelas bolsas de doutorado e pós-doutorado concedidas ao primeiro autor.

\section{Referências bibliográficas}

Baudet, J.C. 1974. Signification taxonomique des caractères blastogèniques dans la tribu des Papilionaceae Phaseoleae. Bulletin du jardin botanique national de Belgique 44: 259-293.

Duke, J.A. 1965. Keys for the identification of seedlings of some prominent woody species in eight forest types in Puerto Rico. Annals of the Missouri Botanical Garden 52: 314-350.

Duke, J.A. 1969. On tropical tree seedlings I. Seeds, seedlings, systems and systematics. Annals of the Missouri Botanical Garden 56: 125-161.

Duke, J.A. \& Polhill, R.M. 1981. Seedlings of Leguminosae. Pp. 941-949. In: R.M. Polhill \& P.H. Raven (eds.). Advances in Legume Systematics. Part 2, Kew, Royal Botanic Gardens.

Förster, P. 1997. Die Keimpflanzen der Tribus Ranunculeae und der Tribus Adonideae Kunth (Ranunculaceae). Flora 192: $133-142$.

Garwood, N.C. 1995. Studies in Annonaceae. XX. Morphology and ecology of seedlings, fruits and seeds of selected Panamanian species. Botanische Jahrbücher und Systematik 117: 1-152.

Garwood, N.C. 1996. Functional morphology of tropical tree seedlings. Pp. 59-129. In: M.D. Swaine (ed.). The ecology of tropical forest tree seedlings. Paris, Unesco.

Ibarra-Manríquez, G.; Martinez Ramos, M. \& Oyama, K. 2001. Seedling functional types in a lowland rain Forest in Mexico. American Journal of Botany 88: 1801-1812.

Lima, H.C. 1985. Diplotropis Benth. (LeguminosaeFaboideae) - estudo dos táxons infragenéricos. Acta Amazonica 15: 61-75.

Lima, H.C. 1990. Tribo Dalbergieae (Leguminosae Papilionoideae) - Morfologia dos frutos, sementes e plântulas e sua aplicação na sistemática. Arquivos do Jardim Botânico do Rio de Janeiro 30: 1-42.
López, J.; Devesa, J.A.; Ruiz, T. \& Ortega-Olivencia, A. 1998. Seedling morphology in Genisteae (Fabaceae) from south-west Spain. Botanical Journal of the Linnean Society 127: 229-250.

Moreira, F.M.S. \& Moreira, F.W. 1996. Características da germinação de sementes de 64 espécies de leguminosas florestais nativas da Amazônia, em condições de viveiro. Acta Amazonica 26: 3-16.

Nemoto, T. \& Ohashi, H. 1993. Seedling morphology of Lespedeza (Leguminosae). Journal of Plant Research 106: 121-128.

Nozzolillo, C. 1985. Seedling morphology and anatomy of eight Cicer species and their taxonomic value. Canadian Journal of Botany 63: 1-6.

Oliveira, D.M.T. 2001. Morfologia comparada de plântulas e plantas jovens de leguminosas arbóreas nativas: espécies de Phaseoleae, Sophoreae, Swartzieae e Tephrosieae. Revista Brasileira de Botânica 24: 85-97.

Parra, P. 1984. Estudio de la morfologia externa de plántulas de Calliandra gracilis, Mimosa albida, Mimosa arenosa, Mimosa camporum y Mimosa tenuiflora. Revista de la Faculdad de Agronomia (Maracay) 13: 311-350.

Pennington, R.T.; Lavin, M.; Ireland, H.; Klitgaard, B.; Preston, J. \& Hu, J-M. 2001. Phylogenetic relationships of basal Papilionoideae legumes based upon sequences of the chloroplast trnL intron. Systematic Botany 26: 537-556.

Pennington, R.T.; Stirton, C.H. \& Schrire, B.D. 2005. Sophoreae. Pp. 227-249. In: G.P. Lewis; B. Schrire; B. Mackinder \& M. Lock (eds.). Legumes of the World. Kew, Royal Botanic Gardens.

Polak, A.M. 1992. Major timber trees of Guyana - a field guide. Wageningen, The Tropenbos Foundation.

Polhill, R.M. 1981. Sophoreae. Pp. 213-230. In: R.M. Polhill \& P.H. Raven (eds.). Advances in Legume Systematics. Part 1, Kew, Royal Botanic Gardens.

Ressel, K.; Guilherme, F.A.G.; Schiavini, I. \& Oliveira, P.E. 2004. Ecologia morfofuncional de plântulas de espécies arbóreas da Estação Ecológica do Panga, Uberlândia, Minas Gerais. Revista Brasileira de Botânica 27: 311-323.

Ricardi, M.; Hernández, C. \& Torres, F. 1987. Morfologia de plántulas de árboles de los bosques del Estado Mérida. Mérida, Talleres Gráficos Universitários.

Rocas, A.N. 2002. Acosmium panamense (Benth.) Yakovlev. Pp. 264-265. In: J. Vozzo (ed.). Tropical Tree Seed Manual. Springfield, USDA.

Rodrigues, R.S. \& Tozzi, A.M.G.A. no prelo. Morfologia de plântulas no clado Vatairea (Leguminosae, Papilionoideae). Rodriguésia.

Ross, J.H. \& Crisp, M.D. 2005 . Brongniartieae. Pp. 253-259. In: G.P. Lewis; B. Schrire; B. Mackinder \& M. Lock (eds.). Legumes of the World. Kew, Royal Botanic Gardens.

Rudd, V.E. 1965. The American species of Ormosia (Leguminosae). Contributions from the United States National Herbarium 32: 279-384. 
Santos, K. \& Kinoshita, L.S. 2003. Flora arbustivo-arbórea do fragmento de floresta estacional semidecidual do Ribeirão Cachoeira, município de Campinas, SP. Acta Botanica Brasilica 17: 325-341.

Souza, L.A.G. \& Silva, M.F. 1998. Tratamentos escarificadores em sementes duras de sete leguminosas nativas da Ilha de Maracá, Roraima, Brasil. Boletim do Museu Paraense Emílio Goeldi, série Botânica 14: 11-32.

Thomas, V. 1991. Structural, functional and phylogenetic aspects of the colleter. Annals of Botany 68: 287-305.

Tillich, H.-J. 2003. Seedling morphology in Iridaceae: indications for relationships within the family and to related families. Flora 192: 220-242.
Vogel, E.F. 1980. Seedlings of Dicotyledons.Wageningen, PUDOC.

Warwick, M.C. \& Pennington, R.T. 2002. Revision of Cyclolobium (Leguminosae-Papilionoideae). Edinburgh Journal of Botany 59: 247-257.

Wink, M. 2003. Evolution of secundary metabolites from an ecological and molecular phylogenetic perspective. Phytochemistry 64: 3-19.

Wojciechowski, M.F.; Lavin, M. \& Sanderson, M.J. 2004. A phylogeny of legumes (Leguminosae) based on analysis of the plastid matk gene resolves many well-supported subclades within the family. American Journal of Botany 91: 1846-1862. 